\title{
THE GROWTH, FLOWERING AND CHEMICAL COMPOSITION OF LEAVES OF THREE ECOTYPES OF Allium ursinum L.
}

\author{
Marzena Błażewicz-Woźniak, Anna Michowska
}

\author{
Department of Cultivation and Fertilization of Horticultural Plants, University of Life Sciences in Lublin, \\ Leszczyńskiego 58, 20-068 Lublin, Poland \\ Poland, e-mail: marzena.wozniak@up.lublin.pl
}

Received: 07.07.2011

\begin{abstract}
The experiment was conducted in the Botanical Garden of UMCS in Lublin. A collection of three ecotypes of Allium ursinum L. from Dukla, Roztocze Region and Bieszczady mountain range, were the subject of our study. The aim of the study was to compare the biometrical features and chemical composition of garlic leaves. There were substantial differences both in growth characteristics and flowering characteristics of the ecotypes of Allium ursinum. The Dukla ecotype formed the longest leaves, whereas the shortest ones were found in the Roztocze ecotype. The Bieszczady ecotype was characterized by the widest leaf blades, the longest leaf stalk and flowering stems as well as the largest diameter of inflorescence. The Roztocze ecotype had the largest number of flowers in an inflorescence, while the Dukla ecotype had the shortest flowering stems and the fewest flowers in an inflorescence. The largest concentration of dry mass in leaves was detected in A. ursinum from Roztocze. The largest concentration of proteins was detected in the leaves of A. ursinum from Bieszczady. The most flavonoids were assayed in the leaves of the Roztocze ecotype of A. ursinum, the fewest in the Dukla one. Phenolic acids were at their highest concentration in the leaves of bear's garlic from Dukla, while the lowest concentration was recorded in the leaves of the ecotype from Bieszczady. The garlic leaves from Dukla had also the highest content of essential oil, while the Roztocze ones had the lowest oil content. The ecotypes of Allium ursinum differed substantially when it comes to the number of components of their essential oils and the amount of selected components.
\end{abstract}

Key words: Allium ursinum L., inflorescence, protein, flavonoids, phenyl acids, essential oil

\section{INTRODUCTION}

The bear's garlic (Allium ursinum L.) has been known to folk medicine for ages. The genus was first described, including its botanical description, in the
1539 herbarium of Hieronymus Bock (C larke, 2001). The healing properties of wild forest garlic were already well known, and its health-promoting action made it an equally valuable component in herbalism as common garlic. The usable part of the plant is usually its delicate and fragile leaves, which should be collected in the first phase of blooming. The bear's garlic is a common "wild" vegetable in Ukraine, Russia, and Caucasus. It is sold on local markets: fresh, pickled or salted. It is becoming increasingly popular in the Czech Republic and Germany ( $€$ u c z a j, 2004). Folk medicine recommends the use of bear's garlic as an anti-scorbutic, fever-fighting, hunger-provoking agent, also recommended in problems with intestines (Janeczko and Sobolewska, 1995).

The bear's garlic (Allium ursinum L.) is characterized by its composition, which is similar to that of common garlic (Ch y b ow ski, 1997; K o h 1 mü n $\mathrm{z}$ e r , 1998). It has a large content of flavonoids (171.2 $\mathrm{mg} \times \mathrm{mg}^{-1}$ protein), carotenoids $\left(3.99 \mathrm{mg} \times \mathrm{mg}^{-1}\right.$ prote-

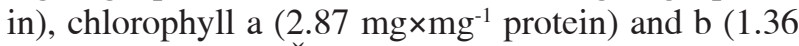
$\mathrm{mg} \times \mathrm{mg}^{-1}$ protein) (Š t a j n e r et al. 2008). Due to the content of allin, allicin and other sulphuric compounds, it is characterized by its parasite-killing, fungicidal and anti-bacterial properties (Chybowski, 1997; Gorecki, 2001; S aniewska and Żuradzka, 2001). In vitro tests have proven that the presence of bear's garlic flavonoids: $\beta$-glucoside and $\beta$-neohesperidose of kaempferol, acts as a slowing agent in aggregation of human blood thrombocytes (C a r o t e n u to et al. 1996). Pre u s s et al. (2001) have even achieved a stronger therapeutic effect of Allium ursinum, when compared with Allium sativum. In exploring the anti-oxidizing properties of bear's garlic oil, G o d e v a ć et al. (2008) have proven its high capabilities in removing radicals and have also stressed the possibility of 
using Allium ursinum in the field of conventional medicine as a drug lowering blood pressure. Numerous scientific studies have proven the highly antioxidant properties of bear's garlic. The analysis of bulbs, leaves, and scapes has shown the activity of, inter alia, SOD (SuperOxide Dismutase), catalase, peroxidase and glutathione peroxidase in all parts of the plant. The strongest antioxidant properties were found in leaves of bear's garlic ( $\breve{S}$ t a j n e r et al. 2008). The analysis of bear's garlic pollen has also shown its high biological value. Particularly its high content of proteins shows that it could potentially be used to fatten honey bees ( $\dot{Z}$ u r a w , 2007).

The aim of the present study was to compare the biometrical features of plants and the chemical composition of leaves of three ecotypes of bear's garlic ( $A l$ lium ursinum L.).

\section{MATERIAL AND METHODS}

The experiment was conducted in the Botanical Garden of the University of Maria Curie-Skłodowska in Lublin (Poland, $51^{\circ} 23^{\prime} \mathrm{N}, 2^{\circ} 56^{\prime} \mathrm{E}$ ). The experiment included a collection of three ecotypes of Allium ursinum L.: from Dukla, Roztocze, and Bieszczady. The bulbs of garlic were planted at $20 \times 30 \mathrm{~cm}$ intervals in four repeating patterns of 50 bulbs in each. The soil for the experiment contained (on average): $1.6 \%$ of humus, 20.0-21.7 mg $\mathrm{P} \times 100 \mathrm{~g}^{-1}$, 6.9-11.7 $\mathrm{mg} \mathrm{K} \times 100 \mathrm{~g}^{-1}$, and $11.3-14.7 \mathrm{mg} \mathrm{Mg} \times 100 \mathrm{~g}^{-1}$ and its reaction was in the range between 6.9 and $7.2 \mathrm{pH}$. Before planting, the soil was cultivated with the use of a rototiller and nitrogen fertilization was applied at a rate of $90 \mathrm{~kg} \mathrm{~N} \cdot \mathrm{ha}^{-1}$ in the form of ammonium nitrate $(34 \% \mathrm{~N})$. The soil surface was covered with pine bark mulch. The plants grew in the vicinity of broad-leaved trees. During the vegetation period, the annual measurements of Allium ursinum ecotypes were taken. The length and width of leaves, the length of leaf stem and of flowering stems were taken. The length of flower stalk, the diameter of inflorescence and the number of flowers per inflorescence were also recorded. Chemical analyses were conducted for the plant material. The garlic leaves were collected in the first stage of blooming. Total $\mathrm{N}$ content was determined with the use of the Kjeldahl method and a Kjeltec System 1002 Distilling Unit, as well as in $2.0 \%$ extract of acetic acid; $\mathrm{K}, \mathrm{Ca}, \mathrm{Mg}$ - with the use of AAS (atomic absorption spectrometry); and $\mathrm{P}$ - colorimetrically. Examination in the last year included the analysis of leaves and determining the sum of all flavonoids, expressed as quercetin equivalents, using spectrophotometry (Polish Pharmacopoeia VII 2008), o-Dihydroxyphenyls (sum) expressed as caffeic acid equivalents using spectrophotometry (S ing let on and R os si, 1965), essential oils (quantitative) using distillation (Polish Phar- macopoeia VII 2008) as well as qualitative, quantitative and semi-quantitative analysis of the content of all oil components with the use of the GC/MS method. The determination was done with a Varium 4000 GC/MS/ MS gas chromatograph. The results were subjected to statistical analysis by variance analysis, with the significance of differences estimated with Tukey's test for the level of significance set at $a=0.05$.

\section{RESULTS}

\section{Biometric features of plants}

The length of leaves of the examined ecotypes of bear's garlic, depending on the year of examination, varied in the range from 70 up to $244 \mathrm{~mm}$ (Table 1). The longest leaves were produced by the plants of the Dukla and Bieszczady ecotypes, the shortest ones by the Roztocze ecotype. The length of leaves increased significantly, $78 \mathrm{~mm}$ on average, during the month between the two measurements. The Roztocze ecotype, whose leaves almost doubled in length reaching 200 $\mathrm{mm}$, was characterized by the fastest pace of growth. Regardless of their growth rate, the leaves of the Roztocze ecotype were significantly shorter when compared with the leaves of the remaining two ecotypes of Allium ursinum. Significant differences in length of garlic leaves were recorded between years. The longest leaves were recorded in all ecotypes in May 2009, with the shortest ones being recorded in 2008.

The width of leaves in April, depending on the ecotype and year of examination, varied between 22 and $59 \mathrm{~mm}$ (Table 1). From April till May, the width increased significantly, $16 \mathrm{~mm}$ on average. The leaves of the Bieszczady ecotype were slightly wider in May, with the Roztocze ecotype characterized by the narrowest leaves. The leaves with the largest diameter were recorded in 2009, while the most slender ones were produced in 2008.

The length of petiole of Allium ursinum in April varied between 25 and $74 \mathrm{~mm}$ (Table 1). The examined ecotypes showed no significant differences in this aspect during the examination. The length of petiole increased significantly within a month, $23 \mathrm{~mm}$ on average. The Bieszczady ecotype of A. ursinum produced the longest petiole, with the Roztocze ecotype having the shortest one. The longest petioles were recorded during the third year of the experiment, the shortest ones in the plants from the first year of the experiment, that is, 2007.

The Bieszczady ecotype produced the longest flowering stems, while the Dukla ecotype of A. ursinum was characterized by the shortest ones (Table 2). The flowering stems were at their longest during the third year of the experiment. The shortest inflorescences were recorded in 2007. 
The diameter of the Allium ursinum inflorescence, depending on the ecotype and the year of examination, varied between 28.3 and $39.4 \mathrm{~mm}$ (Table 2). The inflorescences of the largest diameter were formed by the Bieszczady ecotype of bear's garlic. The remaining two ecotypes did not differ significantly in this aspect, the diameter of their inflorescence being almost $4 \mathrm{~mm}$ shorter than in the Bieszczady ecotype. In 2007 the inflorescences were significantly smaller than in the fol- lowing years of investigation. It was also confirmed by the number of flowers constituting the inflorescence. The inflorescences of bear's garlic contained, on average, 8 to 20 flowers (Table 2). The Roztocze ecotype was characterized by the largest amount of flowers in the inflorescence, while the Dukla one had the fewest. There were differences in the number of flowers between years. The plants had the largest amount of flowers in 2008, the lowest one in 2007.

Table 1

Biometric features of bear's garlic leaves depending on the ecotype in years 2007-2009

\begin{tabular}{|c|c|c|c|c|c|c|c|c|c|c|}
\hline \multirow{2}{*}{ Features } & \multirow{2}{*}{$\begin{array}{c}\text { Ecotype of } \\
\text { Allium ursinum from }\end{array}$} & \multicolumn{2}{|c|}{2007} & \multicolumn{2}{|c|}{2008} & \multicolumn{2}{|c|}{2009} & \multicolumn{3}{|c|}{ Mean } \\
\hline & & IV & V & IV & $\mathrm{V}$ & IV & V & IV & V & Mean \\
\hline \multirow{4}{*}{$\begin{array}{l}\text { Length of leaves } \\
(\mathrm{mm})\end{array}$} & Roztocze & 90 & 151 & 70 & 153 & 194 & 296 & 118 & 200 & 159 \\
\hline & Dukla & 134 & 177 & 121 & 185 & 244 & 353 & 166 & 238 & 202 \\
\hline & Bieszczady & 135 & 188 & 122 & 156 & 213 & 362 & 157 & 235 & 196 \\
\hline & Mean & 120 & 172 & 104 & 165 & 217 & 337 & 147 & 225 & 186 \\
\hline $\mathrm{LSD}_{0.05}$ for: ecotype & & n.s. & n.s. & n.s. & n.s. & n.s. & 64.8 & 30.3 & 30.3 & 17.5 \\
\hline $\begin{array}{l}\text { date of measurement } \\
\text { year }\end{array}$ & & - & 30.3 & - & 30.3 & - & 30.3 & - & 11.9 & $\begin{array}{c}- \\
17.5\end{array}$ \\
\hline \multirow{4}{*}{$\begin{array}{l}\text { Width of leaves } \\
\qquad(\mathrm{mm})\end{array}$} & Roztocze & 44 & 49 & 22 & 52 & 44 & 53 & 37 & 51 & 44 \\
\hline & Dukla & 44 & 49 & 25 & 59 & 55 & 64 & 42 & 57 & 49 \\
\hline & Bieszczady & 59 & 66 & 23 & 52 & 42 & 59 & 41 & 59 & 50 \\
\hline & Mean & 49 & 55 & 24 & 54 & 47 & 59 & 40 & 56 & 48 \\
\hline $\mathrm{LSD}_{0.05}$ for: ecotype & & n.s & n.s. & n.s & n.s. & n.s & n.s. & n.s & n.s. & 4.9 \\
\hline $\begin{array}{l}\text { date of measurement } \\
\text { year }\end{array}$ & & - & n.s. & - & 8.5 & - & 8.5 & - & 3.3 & - \\
\hline \multirow{4}{*}{$\begin{array}{l}\text { Length of petiole } \\
\qquad(\mathrm{mm})\end{array}$} & Roztocze & 25 & 29 & 69 & 62 & 42 & 86 & 45 & 59 & 52 \\
\hline & Dukla & 33 & 37 & 74 & 80 & 59 & 113 & 55 & 77 & 66 \\
\hline & Bieszczady & 29 & 35 & 67 & 80 & 58 & 144 & 51 & 86 & 69 \\
\hline & Mean & 29 & 34 & 70 & 74 & 53 & 114 & 51 & 74 & 62 \\
\hline $\mathrm{LSD}_{0.05}$ for: ecotype & & n.s & n.s. & n.s & n.s. & n.s & n.s. & n.s & 13.9 & 8.0 \\
\hline $\begin{array}{l}\text { date of measurement } \\
\text { year }\end{array}$ & & - & n.s. & - & n.s. & - & 13.9 & - & 5.4 & 8.0 \\
\hline
\end{tabular}

* IV , V - month of measurement; n.s. - no significant differences

Table 2

Biometric features of bear's garlic inflorescences depending on the ecotype in years 2007-2009

\begin{tabular}{|c|c|c|c|c|c|}
\hline Features & Ecotype of Allium ursinum from & 2007 & 2008 & 2009 & Mean \\
\hline \multirow{4}{*}{ Length of flowering stems (mm) } & Roztocze & 222 & 290 & 273 & 262 \\
\hline & Dukla & 189 & 260 & 270 & 240 \\
\hline & Bieszczady & 192 & 328 & 310 & 277 \\
\hline & Mean & 201 & 293 & 284 & 259 \\
\hline $\begin{array}{l}\mathrm{LSD}_{0.05} \text { for: ecotype } \\
\text { year }\end{array}$ & & & & & $\begin{array}{l}\text { n.s. } \\
28.4\end{array}$ \\
\hline \multirow{4}{*}{ Diameter of inflorescence (mm) } & Roztocze & 27.8 & 34.3 & 35.2 & 32.4 \\
\hline & Dukla & 28.3 & 35.2 & 33.8 & 32.4 \\
\hline & Bieszczady & 31.3 & 37.5 & 39.4 & 36.1 \\
\hline & Mean & 29.1 & 35.7 & 36.1 & 33.6 \\
\hline \multirow{2}{*}{$\begin{array}{l}\mathrm{LSD}_{0.05} \text { for: ecotype } \\
\text { year }\end{array}$} & & & & & 3.1 \\
\hline & & & & & 3.1 \\
\hline \multirow{4}{*}{$\begin{array}{l}\text { Number of flowers } \\
\text { per inflorescence }\end{array}$} & Roztocze & 14.6 & 19.6 & 21.0 & 18.4 \\
\hline & Dukla & 13.6 & 20.0 & 8.0 & 13.9 \\
\hline & Bieszczady & 15.6 & 16.4 & 19.8 & 17.3 \\
\hline & Mean & 14.3 & 18.7 & 16.3 & 16.5 \\
\hline \multirow{2}{*}{$\begin{array}{l}\mathrm{LSD}_{0.05} \text { for: ecotype } \\
\text { year }\end{array}$} & & & & & 3.2 \\
\hline & & & & & 3.2 \\
\hline
\end{tabular}

*n.s. - no significant differences 


\section{The chemical composition of leaves}

The leaves of bear's garlic contained, on average, from 6.69 to $15.70 \%$ of dry mass (Table 3 ). The Roztocze ecotype was the one with the highest amount of dry mass, while the Dukla garlic leaves had its lowest content. The amount of dry mass in leaves differed between the years. The bear's garlic produced the largest amount of dry mass in leaves in 2007 and the lowest one in 2008.

The total content of nitrogen in the leaves of bear's garlic ecotypes varied between 2.36 to $3.37 \%$ of dry mass (Table 3 ). A relatively larger concentration of $\mathrm{N}$ was detected in leaves of the Dukla ecotype of garlic, the smallest one in the Roztocze ecotype. The bear's garlic contained a large amount of proteins in its leaves. The average content of this component in the examined A. ursinum ecotypes was $23.61{\mathrm{~g} \times \mathrm{kg}^{-1}}^{-1}$.w. The Bieszczady ecotype contained the largest amount of proteins, while the Dukla garlic had the lowest. No significant differences between $\mathrm{N}$ and protein contents in the leaves of garlic were recorded between the years of the experiment.

Table 3

The content of dry mass, $\mathrm{N}$ and protein in bear's garlic leaves depending on the ecotype in years 2007-2009

\begin{tabular}{|c|c|c|c|c|c|}
\hline Component & Ecotype of Allium ursinum from & 2007 & 2008 & 2009 & Mean \\
\hline \multirow{4}{*}{ Dry mass $(\%)$} & Roztocze & 15.70 & 12.36 & 13.82 & 13.96 \\
\hline & Dukla & 14.14 & 6.69 & 10.19 & 10.34 \\
\hline & Bieszczady & 12.86 & 10.08 & 11.16 & 11.37 \\
\hline & Mean & 14.23 & 9.71 & 11.72 & 11.89 \\
\hline \multirow{2}{*}{$\begin{array}{l}\mathrm{LSD}_{0.05} \text { for: ecotype } \\
\text { year }\end{array}$} & & & & & 0.88 \\
\hline & & & & & 1.93 \\
\hline \multirow{4}{*}{$\mathrm{N}(\%$ d.m.) } & Roztocze & 2.83 & 2.90 & 2.40 & 2.71 \\
\hline & Dukla & 3.37 & 3.17 & 2.88 & 3.14 \\
\hline & Bieszczady & 3.04 & 3.26 & 2.36 & 2.89 \\
\hline & Mean & 3.08 & 3.11 & 2.55 & 2.91 \\
\hline \multirow{2}{*}{$\begin{array}{l}\mathrm{LSD}_{0.05} \text { for: ecotype } \\
\text { year }\end{array}$} & & & & & n.s. \\
\hline & & & & & n.s. \\
\hline \multirow{4}{*}{ Protein (g kg ${ }^{-1}$ f.w.) } & Roztocze & 27.78 & 22.42 & 20.81 & 23.67 \\
\hline & Dukla & 29.78 & 13.26 & 18.31 & 20.45 \\
\hline & Bieszczady & 24.51 & 20.57 & 34.91 & 26.70 \\
\hline & Mean & 27.36 & 18.75 & 24.68 & 23.61 \\
\hline \multirow{2}{*}{$\begin{array}{l}\mathrm{LSD}_{0.05} \text { for: ecotype } \\
\text { year }\end{array}$} & & & & & 6.12 \\
\hline & & & & & n.s. \\
\hline
\end{tabular}

The amount of phosphorus in the leaves of bear's garlic varied between 0.010 and $0.182 \%$ d.m. (Table 4). There were no significant differences in the amount of this element in the examined ecotypes of $\mathrm{Al}$ lium ursinum. The potassium levels, depending on the ecotype, varied between 2.22 and $5.03 \%$ d.m. A little less potassium was detected in the Bieszczady ecotype, whereas the largest concentration was found in the plants from the Dukla ecotype.

The amount of calcium in the leaves of Allium ursinum varied between 0.37 and $2.12 \%$ d.m., depending on the year of the study (Table 4). The garlic of the Dukla ecotype showed a slightly higher concentration of calcium, and a slightly lower concentration was recorded in case of the Bieszczady ecotype. The amount of magnesium in the leaves of bear's garlic was low and, on average, it constituted 0.07 to $0.13 \%$ d.m. The Bieszczady ecotype was characterized by the lowest content of this element, but no significant differences in accumulation of this element were recorded between the three ecotypes. There were no notable differences in the amount of phosphorus, potassium, calcium, and magnesium in the leaves of Allium ursinum recorded between the years of examination.

The content of biologically active substances in the leaves of $A$. ursinum showed little differences (Fig. 1). On average, there was $0.3293 \mathrm{~g}$ of flavonoids expressed as quercetin equivalents in 100 grams of dry leaf mass. The largest amount of these substances was detected in the leaves of the Roztocze ecotype of A. ursinum, the smallest one in the Dukla ecotype. The content of phenolic acids was similar in the leaves of the studied ecotypes of bear's garlic and on average it amounted to $713.7 \mathrm{mg} \times 100 \mathrm{~g} \mathrm{~g}^{-1} \mathrm{~d}$.m. of leaves. The Dukla A.ursinum ecotype was characterized by the largest content of these compounds. The Bieszczady ecotype had the lowest content. The Dukla ecotype of A.ursinum accounted for the largest amount of essential oil, with an average of $0.218 \%$ d.m. The least amount was found in the Roztocze ecotype. 
Table 4

The content of P, K, Ca and Mg in bear's garlic leaves depending on the ecotype in years 2007-2009

\begin{tabular}{|c|c|c|c|c|c|}
\hline Component (\% d.m.) & Ecotype of Allium ursinum from & 2007 & 2008 & 2009 & Mean \\
\hline \multirow{4}{*}{$\mathrm{P}$} & Roztocze & 0.048 & 0.166 & 0.068 & 0.094 \\
\hline & Dukla & 0.014 & 0.182 & 0.046 & 0.081 \\
\hline & Bieszczady & 0.010 & 0.158 & 0.037 & 0.068 \\
\hline & Mean & 0.024 & 0.169 & 0.051 & 0.081 \\
\hline $\begin{array}{l}\mathrm{LSD}_{0.05} \text { for: ecotype } \\
\text { year }\end{array}$ & & & & & $\begin{array}{l}\text { n.s. } \\
\text { n.s. }\end{array}$ \\
\hline \multirow{4}{*}{$\mathrm{K}$} & Roztocze & 3.10 & 4.26 & 3.15 & 3.50 \\
\hline & Dukla & 2.38 & 5.03 & 3.28 & 3.56 \\
\hline & Bieszczady & 3.45 & 4.07 & 2.22 & 3.25 \\
\hline & Mean & 2.98 & 4.45 & 2.88 & 3.44 \\
\hline $\begin{array}{l}\mathrm{LSD}_{0.05} \text { for: ecotype } \\
\text { year }\end{array}$ & & & & & $\begin{array}{l}\text { n.s. } \\
\text { n.s. }\end{array}$ \\
\hline \multirow{4}{*}{$\mathrm{Ca}$} & Roztocze & 0.37 & 1.85 & 1.40 & 1.21 \\
\hline & Dukla & 0.89 & 1.50 & 2.12 & 1.50 \\
\hline & Bieszczady & 0.82 & 1.58 & 1.09 & 1.16 \\
\hline & Mean & 0.69 & 1.64 & 1.54 & 1.29 \\
\hline $\begin{array}{l}\mathrm{LSD}_{0.05} \text { for: ecotype } \\
\text { year }\end{array}$ & & & & & $\begin{array}{l}\text { n.s. } \\
\text { n.s. }\end{array}$ \\
\hline \multirow[t]{4}{*}{ S } & Roztocze & 0.13 & 0.07 & 0.10 & 0.10 \\
\hline & Dukla & 0.09 & 0.11 & 0.13 & 0.11 \\
\hline & Bieszczady & 0.07 & 0.10 & 0.08 & 0.09 \\
\hline & Mean & 0.10 & 0.09 & 0.10 & 0.10 \\
\hline $\begin{array}{l}\mathrm{LSD}_{0.05} \text { for: ecotype } \\
\text { year }\end{array}$ & & & & & $\begin{array}{l}\text { n.s. } \\
\text { n.s. }\end{array}$ \\
\hline
\end{tabular}

g $100 \mathrm{~g}^{-1}$ d.m. Flavonoids - recalculated to quercetin

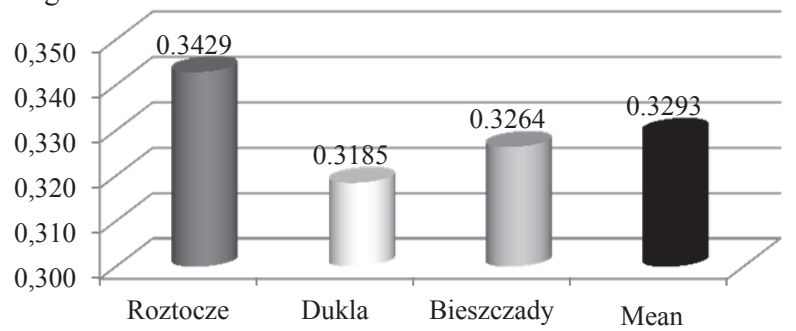

O-Dihydroxyphenyls recalculated to caffeic acid mg $100 \mathrm{~g}^{-1} \mathrm{~d} . \mathrm{m}$.

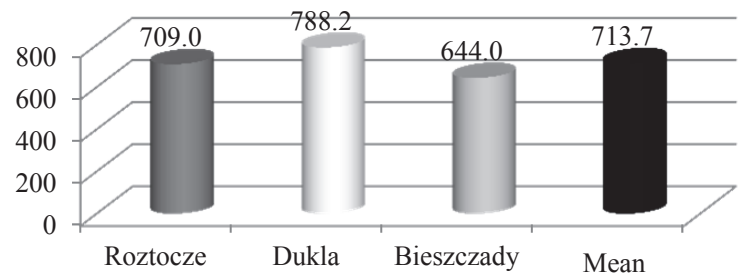

Essential oil in \%

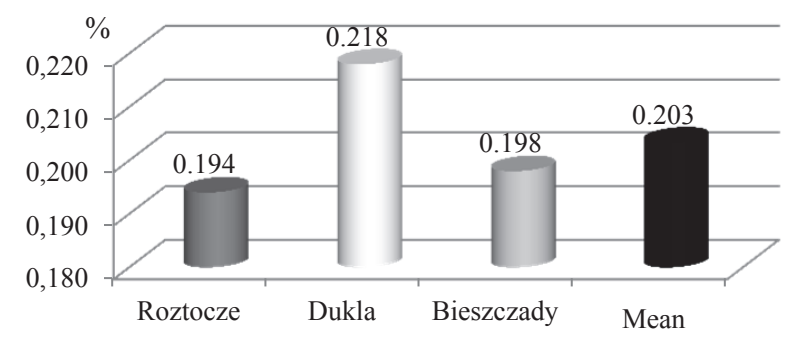

Fig. 1. The content of biologically active substances in the leaves of Allium ursinum depending on the ecotype

A total of 53 compounds were found in the essential oils of the three ecotypes of bear's garlic, but 11 of them remained unidentified (Table 5). The following compounds were the main components of the oil: Ionone $<\left(\right.$ E)-beta - $(10.20 \%)^{*}$; Nonanal $(8.56 \%)^{*}$; Disul- fide, methyl 2-propenyl (7.39\%); Phytol (7.18\%); n-Hexadecanoic acid (7.15\%)*; Phytol acetate (6.56\%)*; Diallyl disulphide $(5.22 \%)^{*}$; Cumene $(4.75 \%)^{*}$; Trisulfide, methyl 2-propenyl (4.55\%)*.

\footnotetext{
${ }^{*}$ The average content for all the treatments.
} 
Table 5

The composition of essential oils from bear's garlic leaves depending on the ecotypes

\begin{tabular}{|c|c|c|c|c|}
\hline \multirow{2}{*}{$\mathrm{N}^{\mathrm{o}}$} & \multirow{2}{*}{ Component in $\%$} & \multicolumn{3}{|c|}{ Ecotype of Allium ursinum from } \\
\hline & & Roztocze & Dukla & Bieszczady \\
\hline 1 & Disulfide, methyl 2-propenyl & $16.05 \pm 0.25$ & $2.45 \pm 0.13$ & $3.67 \pm 0.16$ \\
\hline 2 & Cumene & - & $2.25 \pm 0.14$ & $7.26 \pm 0.80$ \\
\hline 3 & Disulfide, methyl propyl & $0.13 \pm 0.00$ & $0.99 \pm 0.04$ & $1.03 \pm 0.28$ \\
\hline 4 & Disulfide, methyl 1-propenyl & $0.17 \pm 0.00$ & $1.75 \pm 0.07$ & $1.88 \pm 0.42$ \\
\hline 5 & Benzene, 1-ethyl-4-methyl- & -- & $0.12 \pm 0.01$ & -- \\
\hline 6 & Benzene, 1,2,3-trimethyl- & $\operatorname{tr}$. & $2.75 \pm 0.14$ & $6.30 \pm 0.41$ \\
\hline 7 & Trisulfide dimethyl & $12.07 \pm 0.46$ & $2.29 \pm 0.12$ & $3.67 \pm 0.37$ \\
\hline 8 & 5-Hepten-2-one, 6-methyl- & -- & $0.13 \pm 0.00$ & -- \\
\hline 9 & Octanal $<\mathrm{N}->$ & $\operatorname{tr}$. & $0.60 \pm 0.01$ & $0.47 \pm 0.07$ \\
\hline 10 & Cyclohexanone, 2,2,6-trimethyl- & $0.25 \pm 0.00$ & $0.07 \pm 0.02$ & - \\
\hline 11 & $? ?$ & -- & $0.27 \pm 0.02$ & -- \\
\hline 12 & $? ?$ & - & $1.55 \pm 0.15$ & $1.97 \pm 0.19$ \\
\hline 13 & Disulfide, dimethyl & $3.44 \pm 0.04$ & $1.09 \pm 0.07$ & $0.93 \pm 0.07$ \\
\hline 14 & Diallyl disulphide & $6.38 \pm 0.07$ & $1.88 \pm 0.08$ & $7.41 \pm 0.70$ \\
\hline 15 & Nonanal & $11.93 \pm 0.14$ & $5.20 \pm 0.40$ & -- \\
\hline 16 & $? ?$ & - & $\operatorname{tr}$. & - \\
\hline 17 & $? ?$ & $5.19 \pm 0.06$ & $0.16 \pm 0.01$ & - \\
\hline 18 & Trisulfide, methyl 2-propenyl & $3.40 \pm 0.04$ & $4.89 \pm 0.25$ & $5.36 \pm 0.18$ \\
\hline 19 & 1-Propene, 1-(metylthio)-, (Z)- & $0.14 \pm 0.00$ & $1.22 \pm 0.11$ & $0.36 \pm 0.09$ \\
\hline 20 & 1-Propene, 1-(metylthio)-, (E)- & $0.16 \pm 0.00$ & $1.31 \pm 0.16$ & $\operatorname{tr}$ \\
\hline 21 & Decenal & $0.14 \pm 0.00$ & $0.46 \pm 0.02$ & $\operatorname{tr}$ \\
\hline 22 & Tetrasulfide, dimethyl & $0.07 \pm 0.00$ & $1.15 \pm 0.04$ & $0.46 \pm 0.01$ \\
\hline 23 & 1-Cyclohexene-1-acetaldehyde, 2,6,6-trimethyl- & $\operatorname{tr}$ & $0.28 \pm 0.03$ & -- \\
\hline 24 & $\begin{array}{l}\text { 2H-1-Benzopyran, 3,4,4a,5,6,8a-hexahydro-2,5,5,8a- } \\
\text { tetramethyl- }\end{array}$ & $0.43 \pm 0.15$ & $0.48 \pm 0.01$ & $0.57 \pm 0.07$ \\
\hline 25 & 2,6,10,10-Tetramethyl-1-oxa-spiro[4,5]dec-6-ene & $1.26 \pm 0.01$ & $0.27 \pm 0.01$ & - \\
\hline 26 & Trisulfide, di-2-propenyl & $0.19 \pm 0.00$ & $2.83 \pm 0.18$ & $1.82 \pm 0.62$ \\
\hline 27 & $? ?$ & $1.30 \pm 0.33$ & $0.30 \pm 0.02$ & $0.64 \pm 0.00$ \\
\hline 28 & 1-Propene, 3,3'-thiobis- CAS\# 592-88-1 & -- & $2.71 \pm 0.16$ & $1.52 \pm 0.00$ \\
\hline 29 & Tetrasulfide, methyl 2-propenyl & $0.11 \pm 0.00$ & $0.94 \pm 0.04$ & $0.31 \pm 0.00$ \\
\hline 30 & 2-Undecanone, 6,10-dimethyl- & tr. & $0.40 \pm 0.01$ & -- \\
\hline 31 & $? ?$ & - & $0.34 \pm 0.01$ & - \\
\hline 32 & Caryophyllene $<$ E-> & $0.39 \pm 0.00$ & $2.09 \pm 0.12$ & -- \\
\hline 33 & Geranyl acetone & $0.74 \pm 0.06$ & $0.08 \pm 0.00$ & $1.12 \pm 0.20$ \\
\hline 34 & $? ?$ & $0.35 \pm 0.00$ & $0.20 \pm 0.01$ & -- \\
\hline 35 & Aromadendrene $<$ allo- $>$ & $0.63 \pm 0.04$ & $0.19 \pm 0.01$ & - \\
\hline 36 & Ionone $<(\mathrm{E})$-beta- $>$ & $8.95 \pm 0.04$ & $7.77 \pm 0.38$ & $13.33 \pm 1.09$ \\
\hline 37 & Tridecanone $<2->$ & $0.54 \pm 0.01$ & $1.44 \pm 0.09$ & $0.22 \pm 0.00$ \\
\hline 38 & $? ?$ & $0.11 \pm 0.00$ & $0.33 \pm 0.02$ & - \\
\hline 39 & Tetrasulfide, di-2-propenyl & $0.51 \pm 0.01$ & $0.25 \pm 0.03$ & -- \\
\hline 40 & 1,6,10-Dodecatrien-3-ol, 3,7,11-trimethyl- & -- & $0.30 \pm 0.01$ & -- \\
\hline 41 & 2-Hexadecanol & -- & $0.48 \pm 0.01$ & -- \\
\hline 42 & Spathulenol & $0.99 \pm 0.01$ & $0.76 \pm 0.04$ & $0.67 \pm 0.01$ \\
\hline 43 & Caryophyllene oxide & $0.32 \pm 0.00$ & $0.33 \pm 0.03$ & $0.24 \pm 0.02$ \\
\hline
\end{tabular}




\begin{tabular}{|c|c|c|c|c|}
\hline 44 & $? ?$ & $0.47 \pm 0.23$ & $0.95 \pm 0.06$ & -- \\
\hline 45 & Tetradecanal & $1.25 \pm 0.01$ & $0.78 \pm 0.05$ & $1.04 \pm 0.18$ \\
\hline 46 & $? ?$ & $0.23 \pm 0.00$ & $0.92 \pm 0.05$ & $0.85 \pm 0.03$ \\
\hline 47 & Pentadecanal & $0.73 \pm 0.08$ & $3.85 \pm 0.17$ & $1.04 \pm 0.07$ \\
\hline 48 & 2-Pentadecanone, 6,10,14-trimethyl- & $13.55 \pm 0.39$ & $0.89 \pm 0.02$ & $6.72 \pm 0.05$ \\
\hline 49 & $? ?$ & $1.89 \pm 0.10$ & $2.00 \pm 0.12$ & $2.18 \pm 0.01$ \\
\hline 50 & 5,9,13-Pentadecatrien-2-one,6,10,14-trimethyl-,(E,E)- & $2.14 \pm 0.53$ & $1.28 \pm 0.04$ & $3.32 \pm 0.02$ \\
\hline 51 & Phytol & $1.19 \pm 0.07$ & $17.03 \pm 1.19$ & $3.33 \pm 0.05$ \\
\hline 52 & n-Hexadecanoic acid & $1.34 \pm 0.30$ & $16.57 \pm 2.24$ & $3.55 \% \pm 1.06$ \\
\hline 53 & Phytol acetate & $0.85 \pm 0.16$ & $2.45 \pm 0.13$ & $16.40 \pm 4.51$ \\
\hline \multicolumn{5}{|c|}{$\begin{array}{l}(-) \text { - this value was not assayed } \\
(--) \text { - the compound was not detected } \\
\text { ?? - an unidentified compound } \\
\text { CAS\# - in case of the systematic name, the CAS number was given - CAS (Chemical Abstracts Service, www.cas.org) } \\
\text { tr. - trace amounts }\end{array}$} \\
\hline
\end{tabular}

These substances amounted to over $61 \%$ of total oil contents. Large differentiation within the composition of essential oils was detected between the examined ecotypes of bear's garlic. The plants from Dukla had the largest number of essential compounds (53), while the Bieszczady ecotype had the simplest composition of its oil (34). Some of the main substances of the oils of two ecotypes were not detected in the third ecotype of garlic. Cumene, for example, was found in both ecotypes - from the Dukla $(2.25 \%$ on average) and Bieszczady (7.26\%) ecotypes, but was not found in the leaves of the Roztocze ecotype, whereas nonanal was found in the Roztocze $(11.93 \%)$ and Dukla $(5.20 \%)$ ecotypes, but was not detected in the leaves of the Bieszczady garlic. The composition of oils differed greatly in the content of essential substances between the examined ecotypes. Even the dominant components of the oils of the three ecotypes were different. The essential oil of the Roztocze ecotype of Allium ursinum was dominated by Disulphide, methyl 2-propenyl (16.05\% on average), and 2-Pentadecanone, 6,10,14-trimethyl - (13.55\%), Nonanal (11.93\%), and Trisulfide dimethyl (12.07\%), while the content of these two substances in the oil of the remaining two ecotypes was a few times lower. The oil of the Dukla ecotype of garlic was composed mainly of phytol $(17.03 \%)$ and n-Hexadecanoic acid (16.57\%) whereas the oil of the Bieszczady ecotype was dominated by Phytol acetate $(16.40 \%)$ and Ionone $<$ E-beta $(13.33 \%)$.

\section{DISCUSSION}

The comparative study showed differences in length of leaves of different ecotypes of bear's garlic. The longest leaves were produced by the Dukla ecotype (238 $\mathrm{mm}$ on average) and the Bieszczady ecotype
(235 $\mathrm{mm}$ ), the shortest ones by the Roztocze ecotype $(118 \mathrm{~mm})$. In the work of E g g e r t (1992), the length of the leaf blade of Allium ursinum varied between 293 and $326 \mathrm{~mm}$, whereas Kuklová and Kukla (2006) give the average length of bear's garlic leaves as $449 \mathrm{~mm}$. These values are slightly larger than those obtained in our experiment. It only confirms that, when planting those plants, one should aim at creating conditions similar to those which are present in natural habitats of A. ursinum. In 2009 the plants of the Bieszczady ecotype formed leaves of $362 \mathrm{~mm}$ in length (on average). We can also assume that the length of leaves in the study of $\mathrm{Kuklová}$ and $\mathrm{Kukla}$ (2006) was a direct result of age of the plants. Fully formed leaves of bear's garlic, depending on the ecotype, were 53 to $64 \mathrm{~mm}$ in width. The Bieszczady ecotype was characterized by the widest leaves, the Roztocze ecotype by the narrowest ones. The literature reports the width of $A$. ursinum leaves as 20 to $50 \mathrm{~mm}(\mathrm{~S} \mathrm{z}$ a f e r et al. 1986). In the present study, the bear's garlic was able to produce leaves slightly wider than that. In May the Bieszczady ecotype formed the longest petiole (86 $\mathrm{mm}$ on average) and the Roztocze ecotype the shortest one $(59 \mathrm{~mm})$. Those values differ significantly from those given in the literature. According to $\mathrm{S} z$ a f e $\mathrm{r}$ et al. (1986), the length of Allium ursinum petiole varies from 5 to $20 \mathrm{~mm}$. It is hard to explain such a big difference. It may be due to the fact that the petiole of bear's garlic described by $\mathrm{S} z$ a f e r et al. (1986) was a direct result of a specific ecotype.

The length of flower stalks of bear's garlic was $259 \mathrm{~mm}$ on average. The longest stalks were produced by the Bieszczady garlic $(277 \mathrm{~mm})$, the shortest ones by the Dukla ecotype $(240 \mathrm{~mm})$. The length of the bear's garlic scape, according to T r a c z y k (1989), varies between 200 and $500 \mathrm{~mm}$. Allium ursinum coming from the natural reserve "Chynoriansky luh" formed 
inflorescences of 338 to $537 \mathrm{~mm}$ length ( $\mathrm{K} \mathrm{u} \mathrm{k} \mathrm{lov} \mathrm{á}$ and $\mathrm{Kukla}$, 2006). Ernst (1979) gives the height of inflorescence stalks of $A$. ursinum in the range from 186 to $270 \mathrm{~mm}$. The inflorescences of the studied ecotypes of Allium ursinum included 16.5 flowers on average. The highest number of flowers was found in the Roztocze garlic (18.4 on average), the lowest one in the Dukla ecotype (13.9 pcs). According to $\dot{Z}$ u r a w (2005), the inflorescence of bear's garlic consists of 11.8 single flowers on average.

The examined ecotypes of bear's garlic differed in their leaf dry mass content and protein content. The content of $\mathrm{N}, \mathrm{P}, \mathrm{K}, \mathrm{Ca}$ and $\mathrm{Mg}$ was similar in the leaves of all three ecotypes. The highest amount of dry matter was found in the Roztocze ecotype $(13.96 \%$ on average), the lowest one (10.34\%) in the Dukla ecotype. The scientific literature lacks the data on dry mass content in the organs of A.ursinum, but it gives such data for the leaves of early plantations of hard necked garlic from early harvest $-\mathrm{Dyduch}$ and $\mathrm{Najda}$ (2000) found from 10.48 up to $17.93 \%$ of dry mass in it. The leaves of winter garlic from early harvest contained from 15.42 to $16.04 \%$ d.m. (D y d u ch and $\mathrm{N}$ a j d a , 2001). Depending on the ecotype, leaf nitrogen content was $2.91 \% \mathrm{~N}$ in dry matter. The highest nitrogen content was found in the Dukla ecotype, the smallest amount in the Roztocze ecotype. Th o m p s o n et al. (1997) give the concentration of nitrogen for bear's garlic leaves collected in natural conditions as $4.38 \% \mathrm{~N}$ total. Ernst (1979) in turn has shown that the leaves of seven-year-old plants of Allium ursinum contained (on average) $6.30 \%$ of $\mathrm{N}$ in dry mass. Trémolière s et al. (2009) have found from 3.30 up to $5.40 \% \mathrm{~N}$ in the leaves of $A$. ursinum, depending on their phenological phase.

The experiment has also shown that bear's garlic is a relatively rich source of protein. The highest amount of this component $\left(26.7{\mathrm{~g} \times \mathrm{kg}^{-1}}^{-1}\right.$.w.) was detected in the leaves of the Bieszczady ecotype, the lowest one $\left(20.5{\mathrm{~g} \times \mathrm{kg}^{-1}}^{-} \mathrm{f}\right.$.w.) in the leaves of the Dukla ecotype. At present, the literature lacks information regarding the protein content of bear's garlic. According to E $1 \mathrm{madfa}$ et al. (2003), raw garlic (A.sativum) contains $6.1 \mathrm{~g}$ of protein, elephant garlic (A.ampeloprasum) $2.0 \mathrm{~g}$, leek (A.porrum) $2.2 \mathrm{~g}$, and the common onion (A.cepa) just $1.3 \mathrm{~g}$ in each $100 \mathrm{~g}$ of edible parts. A comparison of phosphorus content of different ecotypes of garlic showed that the Roztocze ecotype had the highest concentration of this element $(0.091 \%$ of $\mathrm{P}$ in leaf dry mass), while the Bieszczady garlic was found to contain the least amount $(0.068 \%)$. T r é $\mathrm{m}$ o $\mathrm{l}$ i è r e $\mathrm{s}$ et al. (2009), while examining natural stands of bear's garlic in France, found that leaf phosphorus content changed with the phenological cycle and averaged $3.21 \pm 0.73 \%$ o at the beginning of the vegetation period and $1.75 \pm 0.44 \%$ o during blooming. The ecotypes of bear's garlic amassed an average of $3.44 \%$ of $\mathrm{K}$ in leaf dry mass. The amount of potassium in the leaves of bear's garlic, quoted by the literature, is slightly larger and amounts to $3.86 \%$ (T h o m p s o n et al. 1997). 1.16 to $1.50 \%$ of $\mathrm{Ca}$ was determined in the leaves of different ecotypes of Allium ursinum. The highest calcium content was found in the leaves of the $\mathrm{Dukla}$ ecotype. It corresponds with the results of the study of Thompson et al. (1997) who reported an average of $1.23 \%$ of calcium in bear's garlic leaves. The average content of magnesium in the leaves of the studied ecotypes amounted to $0.10 \%$ d.m. of leaves. This result was higher than the values given by the literature. According to Th o m p s o n et al. (1997), the dry mass of A. ursinum leaves contained $0.042 \%$ of $\mathrm{Mg}$.

The content of biologically active substances in the leaves of bear's garlic depended largely on its ecotype. Flavonoids and phenyl-acids have strong antioxidant properties, which makes them an important addition to the human diet ( $\breve{S}$ tajner and Varga, 2003). Depending on the ecotype, the sum of all flavonoids varied from $0.3185 \mathrm{~g} \times 100 \mathrm{~g}^{-1}$ leaf d.m. of Dukla A. ursinum up to $0.3429 \mathrm{~g}$ in the Roztocze ecotype. The flavonoid content shown in the paper of $\breve{S} t a j$ $\mathrm{n}$ e $\mathrm{r}$ et al. (2008) was significantly lower than the results obtained during our experiment. The leaves of Allium ursinum contained a total of $0.1712 \mathrm{~g}$ of flavonoids, and the bulbs were found to contain $0.0440 \mathrm{~g}$ of them. According to D jurdjević et al. (2004), the leaves of bear's garlic contain $3.24 \mathrm{mg}$ of flavonoids per gram. The content of o-Dihydroxyphenyls (sum), expressed as caffeic acid equivalents, in the leaves of the investigated ecotypes of bear's garlic amounted to an average of $713.7 \mathrm{mg} \times 100 \mathrm{~g}^{-1}$ leaf d.m. The largest content of these substances was found in the Dukla ecotype (788.2 mg $\times 100 \mathrm{~g}^{-1} \mathrm{~d} . \mathrm{m}$.), the lowest one in the Bieszczady garlic $\left(644.0 \mathrm{mg} \times 100 \mathrm{~g} \mathrm{~g}^{-1} \mathrm{~d} . \mathrm{m}\right.$.). These results are higher than those given by $\mathrm{D} j \mathrm{u}$ r d j e vi ć et al. (2004). According to these authors, the total content of phenyl compounds in leaves of Allium ursinum was $434 \mathrm{mg}$ in $100 \mathrm{~g}$.

The multitude of actions of the essential oil, including germ killing, prevention of arteriosclerosis, fibrinolitic actions, slowing down the aggregation of blood platelets, anti-cancer and anti-inflammatory properties and strengthening of human immune system (Kędzia, 2009), makes its content and composition an essential factor in estimating its biological value. The oil content in the leaves of garlic varied, depending on the ecotype, from $0.194 \%$ in the leaves of the Roztocze ecotype up to $0.218 \%$ in the Dukla ecotype. While investigating the chemical composition of bear's garlic, S c h mit t et al. (2005) were able to confirm that the content of cysteine sulphoxide derivates 
varied, depending on the time of harvest, from $0.42 \%$ to $0.10 \%$ in the leaves and from $0.35 \%$ to $0.06 \%$ in the bulbs of garlic. S e ndl (1995) set the alliin content in garlic leaves at $0.410 \%$ (on average). The essential oil distilled from the leaves of three ecotypes of Allium ursinum contained 53 chemical compounds. The dominant components of garlic oils were: Ionone $<(\mathrm{E})$ -beta-; Nonanal; Disulfide, methyl 2-propenyl; Phytol; n-Hexadecanoic acid; Phytol acetate; Diallyl disulphide; Cumene; Trisulfide, methyl 2-propenyl. Aromatic compounds, which were the main constituents of the examined ecotypes of bear's garlic, were as follows: Phytol, n-Hexadecanoic acid, Phytol acetate and Diallyl disuphide. The examined ecotypes differed greatly in their content of specific compounds. The chemical composition of Allium ursinum leaves, as determined during our experiment, is confirmed by the literature S ch mitt et al. (2005) have isolated 21 compounds constituting the oil of bear's garlic leaves and bulbs. The chemical composition of garlic oils investigated in our experiment confirmed the presence of ten compounds isolated by G o d e v a ć et al. (2008). These were: Disulfide methyl 2-propenyl, Disulfide, methyl propyl; Disulfide, (e)-methyl 1-propenyl; Trisulfide dimethyl; Nonanal; Trisulfide, methyl 2-propenyl; Tetrasulfide dimethyl; Trisulfide, di-2-propenyl; Tetrasulfide, methyl 2-propenyl and tetrasulfide, di-2-propenyl.

\section{CONCLUSIONS}

1. The ecotypes of Allium ursinum differed significantly in their growth and blooming characteristics. The longest leaves were formed by the Dukla ecotype, while the slowest leaf growth was observed in case of the Roztocze ecotype. The Bieszczady ecotype was characterized by the widest leaf blade, the longest leaf stalks and flowering stems as well as the largest diameter of its inflorescence. The Roztocze ecotype had the largest number of flowers in its inflorescence. The Dukla ecotype formed the shortest flowering stems with the fewest flowers in the inflorescence.

2. The highest amount of dry mass in leaves was accumulated by the Roztocze ecotype of $A$. ursinum, the highest amount of protein - by the Bieszczady one. There were no significant differences in N, P, K, Ca and $\mathrm{Mg}$ contents in the leaves of the ecotypes under study.

3. The ecotypes of bear's garlic differed significantly in their content of biologically active agents. The Roztocze A. ursinum contained the largest number of flavonoids, while the Dukla ecotype had the least. The largest number of phenyl acids was found in the Dukla ecotype's leaves, the lowest one in the Roztocze ecotype.
4. The Allium ursinum ecotypes differed significantly when it comes to the number of compounds and their content in the essential oils. The highest number of essential compounds was found in Dukla garlic, the lowest amount of compounds in the leaves of the Bieszczady ecotype.

The research was financed from budget funds for science in 2010-2011 as a research project N N310 451038

\section{REFERENCES}

Carotenuto A., De Feo V., Fattorusso E., Lanzotti V., Magno S., Cicala C., 1996. The flavonoids of Allium ursinum. Phytochemistry, 41(2): 531-536.

Chybowski J., 1997. Badanie aktywności przeciwrobaczej wyciągów czosnkowych. / Study of the anthelmintic activity of garlic extracts. Herba Polonica, 43(4): 383-387. (in Polish)

Clarke Oz R ., 2001. The Encyclopedia of Grapes. Websters Int. Publ. ISBN 0151007144: 192.

Djurdjević L., Dinić A., Pavlović P., Mitrović M., Karadzić B., Tesević V., 2004. Allelopathic potential of Allium ursinum L. Biochem. System. and Ecol. 32(6): 533-544.

Dyduch J., Najda A., 2000. Analiza składu chemicznego liści czosnku strzałkującego w uprawie wczesnej na zbiór pęczkowy. / Estimation of the chemical composition of winter garlic leaves from early cultivation on bunch crop. Rocz. AR Pozn., Ogrod. 31 (323), 2: 253257. (in Polish)

Dyduch J., Najda A., 2001. Estimation of the biological value of winter garlic leaves from early cultivation on bunch crop. Part II. Plants grown from planting air bulbs. EJPAU 4(2): 4.

Eggert A., 1992. Dry matter economy and reproduction of a temperate forest spring geophyte, Allium ursinum. Ecography, 15: 45-53.

Elmadfa I., Aign W., Muskat E., Fritzsche D., 2003. Die große GU Nährwert Kalorien Tabelle - Neuausgabe 2004/05. Gräfe und Unzer, München: 128.

Ernst H.O. 1979. Population biology of Allium ursinum in northern Germany. J. Ecology, 67: 347-362.

Godevać D., Vujisić L., Mojović M., Ignjatović A., Spasojević I., Vajs V. 2008. Evaluation of antioxidant capacity of Allium ursinum L. volatile oil and its effect on membrane fluidity. Food Chem. 107: 1692-1700.

Gorecki P., 2001. Surowce roślinne w lecznictwie i profilaktyce, w żywieniu i kosmetyce. / Vegetative raw materials in medicine and prevention, in nutrition and cosmetics. Herba Pol. 47(2): 85-101. (in Polish)

Janeczko Z., Sobolewska D., 1995. Czosnek niedźwiedzi - cenna roślina lecznicza. / Bear's garlic - a valuable herbal plant. Wiad. Ziel. 4: 12-14. (in Polish) 
Kędzia A., 2009. Olejek czosnkowy - skład chemiczny, działanie farmakologiczne i lecznicze. / Garlic oil - chemical composition, pharmacological and therapeutic effect. Post. Fitoterapii 3: 198-203. (in Polish)

Kohlmünzer S., 1998. Farmakognozja. Wyd. Lekarskie PZWL Warszawa: 510-511.

Kuklová M., Kukla J., 2006. Natural Reserve Chynoriansky luh floodplain, its ecology and biometry of dominant herb species. Ekológia (Bratislava), 25(4): 341-351.

Łu c z aj Ł., 2004. Dzikie rośliny jadalne Polski. Wyd. Chemigrafia, Krosno: 53-56. (in Polish)

Preuss H.G., Clouatre D., Mohamadi A., Jarrell S.T., 2001. Wild garlic has a greater effect than regular garlic on blood pressure and blood chemistries of rats. Int. Urol. Nephrology, 32: 525-530.

Saniewska A., Żuradzka I., 2001. Porównanie fungistatycznych właściwości czterech odmian czosnku (Allium sativum L.) na przykładzie kilku gatunków patogenicznych grzybów. / Comparison of fungistatic properties of four varieties of garlic (Allium sativum L.) on the example of several species of pathogenic fungi. Folia Hort. 13/1A: 405-412. (in Polish)

Schmitt B., Schulz H., Storsberg J., Keusgen M., 2005. Chemical characterization of Allium ursinum L. depending on harvesting time. J Agric Food Chem. 7, 53(18): 7288-7294.

Sendl A., 1995. Allium sativum and Allium ursinum: Part 1. Chemistry, analysis, history, botany. Phytomedicine, 1: 323-339.

Singleton V.L., Rossi J.A. Jr., 1965. Colorimetry of Total Phenolics with Phosphomolybdic-Phosphotungstic Acid Reagents. Am. J. Enol. Vitic. 16(3): 144-158.

Štajner D., Popović M.B., ČanadanovićBrunet J., Štajner M., 2008. Antioxidant and scavenger activities of Allium ursinum. Fitoterapia, 79: 303-305

Štajner D., Varga I.S., 2003. An evaluation of the antioxidant abilities of Allium species. Acta Biol. Szeged 47 (1-4): 103-106.

Szafer W., Kulczyński S., Pawłowski B., 1986. Rośliny polskie. Część II. Państwowe Wydawnictwo Naukowe Warszawa: 778-779. (in Polish)

Thompson K., Parkinson J.A., Brand S.R., Spencer R.E., 1997. A comparative study of leaf nutrient concentrations in a regional herbaceous flora. New Phytol. 136: 679-689.

Traczyk T., 1989. Rośliny lasu liściastego. Wyd. Szkolne i Pedagogiczne, Warszawa: 104-105. (in Polish)
Trémolières M., Noël V., Hérault B., 2009. Phosphorus and nitrogen allocation in Allium ursinum on an alluvial floodplain (Eastern France). Is there an effect of flooding history? Plant Soil, 324: 279-289.

Żu raw B ., 2005. Wpływ owadów zapylających na wiązanie owoców i masę nasion 14 dzikich gatunków czosnku (Allium L.). / Effect of pollinators on fruit set and seed weight of 14 wild species of garlic. Mat. XLII Nauk. Konf. Pszczelarskiej, Puławy 2005, Wyd. ISiK Oddz. Pszczelnictwa: 128-130. (in Polish)

Żu raw B., 2007. Biological value and morphological traits of pollen of selected garlic species Allium L. Acta Agrobot. 60(1): 67-71.

\section{Wzrost, kwitnienie i skład chemiczny liści trzech ekotypów Allium ursinum $\mathbf{L}$.}

\section{Streszczenie}

Doświadczenie przeprowadzono w Ogrodzie Botanicznym UMCS w Lublinie. Badaniami objęto kolekcję 3 ekotypów Allium ursinum L.: z Dukli, Roztocza i Bieszczad. Celem badań było porównanie cech biometrycznych roślin i składu chemicznego liści czosnku niedźwiedziego. Ekotypy A. ursinum różniły się istotnie cechami wzrostu i kwitnienia roślin. Najdłuższe liście wytworzył ekotyp z Dukli, a najsłabszy wzrost liści stwierdzono w ekotypie roztoczańskim. Ekotyp z Bieszczad charakteryzował się najszerszą blaszką liściową oraz najdłuższymi ogonkami liściowymi, pędem kwiatostanowym a także średnicą kwiatostanu. Największą liczbę kwiatów w kwiatostanie posiadały rośliny ekotypu z Roztocza. Ekotyp z Dukli tworzył najkrótsze pędy kwiatostanowe a w jego kwiatostanach było najmniej kwiatów. Najwięcej suchej masy w liściach gromadził A. ursinum z Roztocza zaś białka - z Bieszczad. Najwięcej flawonoidów oznaczono w liściach $A$. ursinum z Roztocza, a najmniej - z Dukli. Najwięcej kwasów fenolowych zawierały liście ekotypu z Dukli a najmniej - z Bieszczad. Najwięcej olejku stwierdzono w liściach czosnku z Dukli, a najmniej z Roztocza. Ekotypy A. ursinum różniły się znacznie liczbą składników olejku eterycznego oraz zawartością poszczególnych związków. 